\title{
Epstein-Barr virus and cytomegalovirus reactivation after allogeneic hematopoietic cell transplantation in patients with non-Hodgkin lymphoma: the prevalence and impacts on outcomes
}

\section{EBV and CMV reactivation post allo-HCT in NHL}

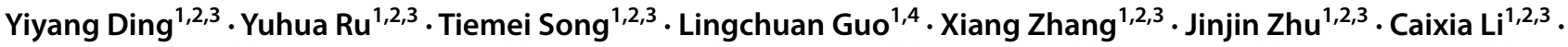

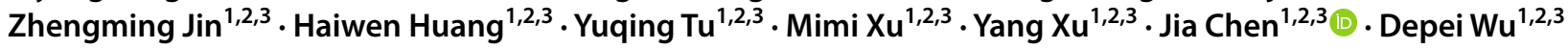

Received: 6 July 2021 / Accepted: 18 August 2021 / Published online: 4 September 2021

(c) The Author(s) 2021

\begin{abstract}
Epstein-Barr virus (EBV) and cytomegalovirus (CMV) reactivations are common complications after allogeneic hematopoietic cell transplantation (allo-HCT), but data focusing on non-Hodgkin lymphoma (NHL) are limited. We retrospectively analyzed the prevalence of EBV and CMV reactivation post-allo-HCT and the impacts on transplant outcomes in $160 \mathrm{NHL}$ patients. The 1-year incidences of EBV and CMV reactivation were $22.58 \%$ and $25.55 \%$, respectively. Independent impactors for EBV reactivation were more than 6 lines of chemotherapy $(P=0.030)$, use of rituximab $(P=0.004)$, and neutrophil recovery within 30 days post-HCT $(P=0.022)$. For T-cell lymphoblastic lymphoma patients, the International Prognostic Index (IPI) $(P=0.015)$ and chronic GVHD $(P=0.001)$ increased the risk of CMV reactivation. CMV reactivation was independently related to a lower risk of relapse $(P=0.027)$ but higher transplant-related mortality $(\mathrm{TRM})(P=0.038)$. Although viral reactivation had no significant impact on overall survival (OS) in the whole cohort, it led to an inferior 2-year OS (67.6\% versus $92.5 \%, P=0.005)$ and TRM $(20.1 \%$ versus $4.7 \%, P=0.020)$ in recipients surviving for more than 180 days. We concluded that EBV and CMV reactivation post-allotransplant still deserved concern particularly in NHL patients with high-risk factors, since it is generally related to a deteriorated prognosis. Large-scale studies are warranted to validate our findings.
\end{abstract}

Keywords Epstein-Barr virus · Cytomegalovirus · Non-Hodgkin lymphoma $\cdot$ Allogeneic hematopoietic cell transplantation

Yiyang Ding, Yuhua Ru, and Tiemei Song are co-first authors.

Jia Chen

chenjia@suda.edu.cn

$\triangle$ Depei Wu

wudepei@suda.edu.cn

1 National Clinical Research Center for Hematologic Diseases, Jiangsu Institute of Hematology, The First Affiliated Hospital of Soochow University, Shizi Street 188, Suzhou 215006, China

2 Institute of Blood and Marrow Transplantation, Collaborative Innovation Center of Hematology, Soochow University, Suzhou, China

3 Key Laboratory of Stem Cells and Biomedical, Materials of Jiangsu Province and Chinese Ministry of Science and Technology, Suzhou, China

4 The pathology department of the First Affiliated Hospital of Soochow University, Suzhou, China

\section{Introduction}

Patients with relapsed and refractory (R/R) non-Hodgkin lymphoma (NHL) have a dismal prognosis. Despite emerging agents and cellular therapies, allogeneic hematopoietic cell transplantation (allo-HCT) remains an essential modality to attain long-term survival [1-3]. However, transplant outcomes are impaired by all kinds of complications.

Epstein-Barr virus (EBV) and cytomegalovirus (CMV) reactivations are frequent complications after allo-HCT that could cause fatal virus-related diseases [4-6]. Moreover, EBV per se has been causally linked to the pathogenesis of several types of NHL [7, 8] or posttransplant lymphoproliferative diseases (PTLDs). The reported incidences fluctuate widely from 0.1 to $63 \%$ for EBV [9] and from 30 to $70 \%$ for CMV reactivation after HCT [10-13] with ambiguous impacts on transplant outcomes [14-18], but limited data 
focusing on NHL patients have been reported. Hence, we conducted a retrospective analysis to investigate the features of EBV and CMV reactivation after allo-HCT in NHL patients.

\section{Materials and methods}

\section{Patients}

This was a retrospective study based on data from the transplant database in our center, which was established according to the European Society for Blood and Marrow Transplantation registry. The inclusion criteria included (1) patients who were histologically diagnosed with NHL; (2) patients who underwent allo-HCT between January 2010 and December 2018; and (3) patients who received regular EBV and CMV monitoring after HCT based on an institutional protocol. The study protocol was approved by the Ethics Committee of our center and conducted in accordance with the Helsinki Declaration.

\section{Transplant protocol}

NHL patients with the following indications were recommended to receive allo-HCT in our center: (1) refractory to more than 2 lines of chemotherapy; (2) relapsed within 1 year after the completion of treatment, or had a history of autologous HCT; (3) lymphoblastic lymphoma (LBL), highly aggressive T-cell NHL, or transformed diffuse large B-cell lymphoma (DLBCL) arising from follicular lymphoma or chronic lymphocytic leukemia, etc. Donor selection was based on HLA typing, age, donor sex, ABO compatibility, and physical health [19]. An HLA-matched sibling was preferred, and a matched unrelated donor, a haploidentical donor, or umbilical cord blood units could be an alternative option [20]. Donors were encouraged to contribute a bone marrow graft, and peripheral blood stem cells were collected if the CD34 + cell dose was less than the target dose of $2 \times 10^{6} / \mathrm{kg}$ of recipient body weight. All patients in this cohort received myeloablative conditioning (MAC), including the modified $\mathrm{Bu} / \mathrm{Cy}$ regimen and the modified TBI/Cy regimen [21].

The prophylaxis of graft-versus-host disease (GVHD) was included cyclosporin A (CsA) and short-term methotrexate for recipients receiving HLA-matched sibling donor grafts, and mycophenolate mofetil (MMF) combined with antithymocyte globulin (ATG) (Genzyme, MA, USA) [22] was added to unrelated or haploidentical donor HCT. Acute and chronic GVHD was diagnosed according to reference literature [23, 24].

\section{Management of virus reactivation}

Q-PCR was applied to monitor EBV-DNA and CMV-DNA load in whole peripheral blood weekly from conditioning to +90 days post-HCT in all patients and once every 2 weeks from +90 days until +180 days. Additional detection was performed if symptoms of suspected virus infection were present in individual situations. Ganciclovir $5 \mathrm{mg} / \mathrm{kg}$ twice a day or foscarnet $90 \mathrm{mg} / \mathrm{kg}$ twice a day was routinely used from -9 to -2 days to prevent virus infection and then replaced by acyclovir to avoid marrow toxicity. The treatment for reactivation included ganciclovir, foscarnet, and tapering of immunosuppressive agents. Preemptive rituximab was prescribed if EBV-DNA reached $10^{5}$ copies $/ \mathrm{mL}$ or $10^{4}$ copies $/ \mathrm{mL}$ for 2 consecutive weeks.

\section{Definition}

EBV and CMV reactivation was defined as more than $10^{2}$ copies/mL DNA load in our center. Neutrophil recovery was defined as the first day when neutrophil count was above $0.5 \times 10^{9} / \mathrm{L}$ for three consecutive days after HCT, and platelet recovery was defined as the first day when the platelet count was above $20 \times 10^{9} / \mathrm{L}$ for seven consecutive days without transfusion. Advanced disease status at transplant was defined as all disease statuses except complete remission (CR). OS was defined as the duration from transplantation to death from any cause. Progression-free survival (PFS) was defined as survival without disease relapse or progression. Deaths unrelated to the underlying disease were recorded as transplant-related mortality (TRM). GRFS was defined as survival in the absence of grade II-IV acute GVHD, extensive chronic GVHD, relapse, or death from any cause after allo-HCT.

\section{Statistics}

The incidence of virus reactivation, OS, PFS, and graft-versus-host disease-free and relapse-free survival (GRFS) was calculated using the Kaplan-Meier method and compared with the log-rank test. The cumulative incidence of disease relapse or progression (CIR) was calculated by a competing risk model with TRM as a competing risk factor. Risk analyses were conducted by the Cox regression model, and all risk factors whose $P$ values were below 0.1 in univariate analyses were included in multivariate analyses. EBV and CMV reactivations were treated as time-dependent variables in the risk analyses. Since neutrophil recovery was correlated with platelet recovery (Pearson correlation coefficient of $0.40, P<0.001$ ), only neutrophil recovery was enrolled in multivariate analysis if $P$ value of both variables was below 
Table 1 Characteristics of patients undergoing allogeneic HCT

\begin{tabular}{llll}
\hline & Cases & $\mathrm{EBV}+$ & $\mathrm{CMV}+$ \\
\hline Sex & & & \\
Male & 107 & 24 & 28 \\
Female & 53 & 11 & 12 \\
Median age (year) & & &
\end{tabular}

30

Lymphoma classification

B-cell lymphoblastic lymphoma

Non-lymphoblastic B-cell lymphoma

T-cell lymphoblastic lymphoma

Non-lymphoblastic T-cell lymphoma

Autologous HCT before allo-HCT

No

Yes

CAR-T cell therapy before allo-HCT

No

Yes

Disease status before allo-HCT

CR

Advanced status

Donor type

HLA-matched donors

HLA-mismatched donors

Type of graft

BM

PB

$\mathrm{BM}+\mathrm{PB}$

dUCB

IPI stratification

Low risk

Low-intermediate risk

High-intermediate risk

High risk

NCCN-IPI stratification

Low risk

Low-intermediate risk

High-intermediate risk

Ann Arbor

I

II

III

IV

Time from diagnosis to HCT

$$
<8 \mathrm{~m}
$$

$\geq 8 \mathrm{~m}$

Chemotherapy lines

\begin{tabular}{llll}
$<6$ & 78 & 11 & 14 \\
$\geq 6$ & 82 & 24 & 26 \\
ATG use & & & \\
No & 54 & 4 & 10 \\
Yes & 106 & 31 & 30 \\
\hline
\end{tabular}

Table 1 (continued)

\begin{tabular}{|c|c|c|c|}
\hline & Cases & $\mathrm{EBV}+$ & $\mathrm{CMV}+$ \\
\hline \multicolumn{4}{|l|}{ TBI use } \\
\hline No & 108 & 24 & 15 \\
\hline Yes & 52 & 11 & 25 \\
\hline \multicolumn{4}{|l|}{ Rituximab } \\
\hline No & 117 & 34 & 27 \\
\hline Yes & 43 & 1 & 13 \\
\hline \multicolumn{4}{|c|}{ Prophylactic therapy } \\
\hline Ganciclovir & 83 & 20 & 21 \\
\hline Foscarnet & 50 & 11 & 12 \\
\hline Acyclovir & 27 & 4 & 7 \\
\hline \multicolumn{4}{|c|}{ Neutrophil recovery within 30 days } \\
\hline No & 7 & 2 & 2 \\
\hline Yes & 153 & 33 & 38 \\
\hline \multicolumn{4}{|c|}{ Platelet recovery within 60 days } \\
\hline No & 37 & 9 & 31 \\
\hline Yes & 123 & 26 & 9 \\
\hline \multicolumn{4}{|l|}{ Acute GVHD } \\
\hline None & 82 & 19 & 17 \\
\hline Acute GVHD & 78 & 16 & 23 \\
\hline None, grade I & 96 & 22 & 19 \\
\hline Grades II-IV & 64 & 13 & 21 \\
\hline \multicolumn{4}{|l|}{ Chronic GVHD } \\
\hline None & 115 & 28 & 27 \\
\hline Chronic GVHD & 45 & 7 & 13 \\
\hline None, limited & 139 & 30 & 33 \\
\hline Extensive & 21 & 5 & 7 \\
\hline
\end{tabular}

Abbreviations: NHL non-Hodgkin lymphoma; EBV Epstein-Barr virus; $C M V$ human cytomegalovirus; $C R$ complete remission; $B M$ bone marrow; $P B$ peripheral blood; $d U C B$ double umbilical cord blood graft; IPI the International Prognostic Index; $A T G$ antithymocyte globulin; $T B I$ total body irradiation; $G V H D$ graft-versus-host disease

0.1 in univariate analyses. All tests were two-sided, and $P$ values $<0.05$ were considered statistically significant. Statistical analyses were performed using SPSS 22.0 software (SPSS, Chicago, IL, USA) and the R 3.6.2 software package (The R Foundation for Statistical Computing, Vienna, Austria).

\section{Results}

\section{Patient characteristics}

A total of 160 patients were included according to the inclusion criteria, and the median time from diagnosis to transplantation was 8 months. The patient characteristics are summarized in Table 1. The enrolled patients consisted of 107 males and 53 females, with a median age of 30 (range, 5-59) 
years old at the time of allo-HCT. Of the 160 cases, 85 were LBL, 23 were DLBCL, 13 were peripheral T cell lymphoma, 10 were NK/T cell lymphoma, 7 were Burkitt lymphoma, 6 were anaplastic large cell lymphoma, 4 were mantle cell lymphoma, 3 were aggressive NK cell lymphoma, 2 were
Richter syndrome, 2 were high-grade B-cell lymphoma, 2 were liver and spleen $\gamma \delta$ T-cell lymphoma, 1 was angioimmunoblastic lymphoma, 1 was follicular lymphoma (grade 3 ), and 1 was gray zone lymphoma. Nine patients received an autologous HCT before allo-HCT with a median interval

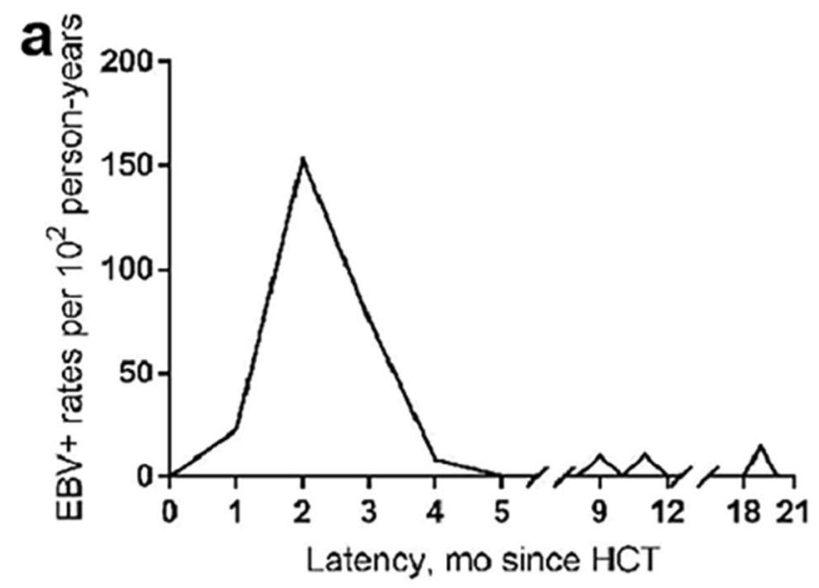

C
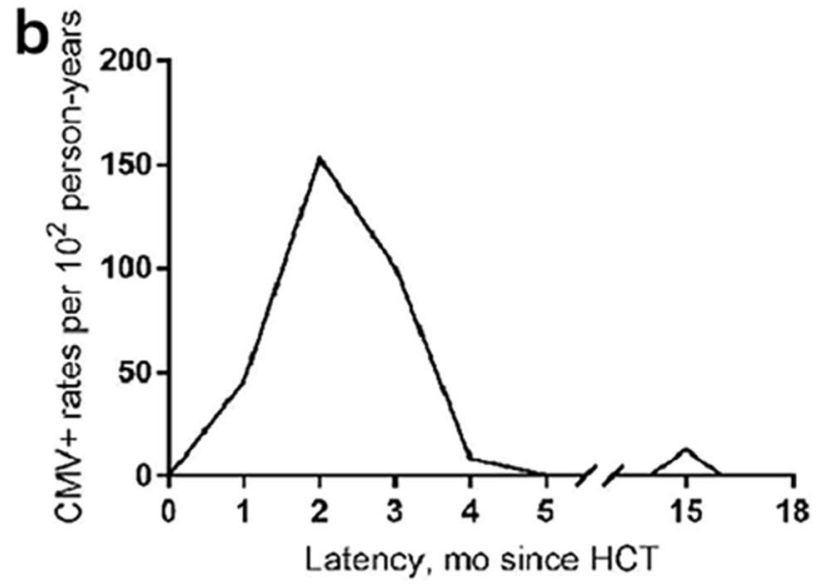

$\mathbf{P}$

$\mathrm{HR}(95 \% \mathrm{Cl})$

0.022

$0.108(0.016-0.722)$

0.004

$0.054(0.007-0.404)$

0.066

$4.060(0.910-18.123)$

0.434

$1.463(0.564-3.797)$

HLA-mismatched donors

Autologous HCT before allo-HCT

Chemotherapy lines $\geq 6^{\star}$

Advanced disease status

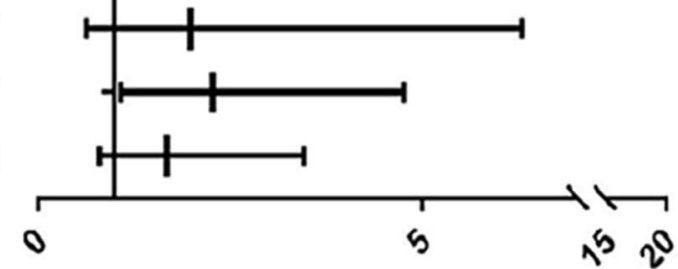

0.246

$1.984(0.624-6.306)$

0.030

$2.272(1.082-4.770)$

0.162

$1.677(0.813-3.458)$

Time from diagnosis to HCT

Chemotherapy Lines

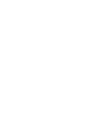

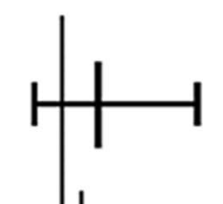

$\mathbf{P}$

0,324

$1,246(0,805-1,930)$

0.578

$1.130(0.735-1.738)$

0.092

$\mathrm{HR}(95 \% \mathrm{Cl})$

$1.307(0.957-1.785)$

aGVHD

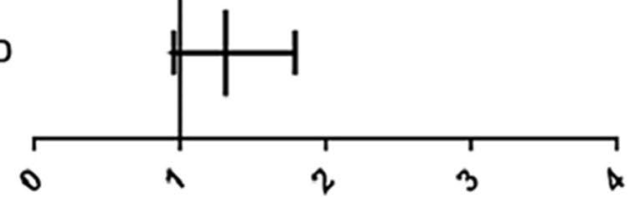

Fig. 1 Incidences and risk factors of viral reactivation. a Variation tendency of EBV reactivation incidence rate over time. b Variation tendency of CMV reactivation incidence rate over time. c Multivari- ate Analysis of EBV reactivation. d Multivariate analysis of CMV reactivation. *Significant differences are marked with an asterisk at the $P$ value stated 
Table 2 The 100-day incidence of virus reactivation post-HCT in subgroup analysis

\begin{tabular}{|c|c|c|c|}
\hline & \multicolumn{2}{|l|}{ Incidence } & \multirow[t]{2}{*}{$P$} \\
\hline & T-cell & B-cell & \\
\hline \multicolumn{4}{|l|}{ EBV } \\
\hline lymphoblastic lymphoma & $21.48 \% \pm 5.29 \%$ & $28.57 \% \pm 9.86 \%$ & 0.516 \\
\hline $\begin{array}{l}\text { Non-lymphoblastic } \\
\text { lymphoma }\end{array}$ & $36.93 \% \pm 8.87 \%$ & $2.78 \% \pm 2.74 \%$ & 0.004 \\
\hline$P$ & $\mathbf{0 . 0 3 8}$ & $\mathbf{0 . 0 2 3}$ & \\
\hline \multicolumn{4}{|l|}{ CMV } \\
\hline $\begin{array}{l}\text { Lymphoblastic lym- } \\
\text { phoma }\end{array}$ & $18.04 \% \pm 4.93 \%$ & $31.82 \% \pm 9.93 \%$ & 0.256 \\
\hline $\begin{array}{l}\text { Non-lymphoblastic } \\
\text { lymphoma }\end{array}$ & $23.40 \% \pm 7.78 \%$ & $30.02 \% \pm 7.58 \%$ & 0.687 \\
\hline $\boldsymbol{P}$ & 0.550 & 0.964 & \\
\hline
\end{tabular}

of 11 months between the two transplants, and 7 patients received a previous CAR-T cell therapy. Only 43 patients had matched-related donors, while others received grafts from HLA-matched unrelated donors $(n=23)$, haploidentical related donors $(n=90)$, HLA-mismatched donors $(n=2)$, and HLA-mismatched umbilical cord blood $(n=2)$.

\section{Prevalence of virus reactivation}

EBV-DNA and CMV-DNA detection was performed in all the donors and recipients before HCT, and the results were negative except for 4 recipients who were EBV-positive. Two of the 4 recipients received rituximab and became negative before transplant, and the other two remained positive even after HCT.

Thirty-five recipients developed EBV reactivation after HCT, while 40 developed CMV reactivation, with a median time of 55 (IQR 43-69) days and 51 (IQR 36.5-62.5) days after HCT, respectively. Viral reactivation after 100 days post-HCT occurred in only 6 patients (3 with EBV reactivation and another 3 with $\mathrm{CMV}$ reactivation). The 1-year incidences of EBV and CMV reactivation were similar as $22.58 \% \pm 3.48 \%$ and $25.55 \% \pm 3.59 \%$, respectively (Fig. 1). Co-reactivation of EBV and CMV was observed in 10 patients. The 1-year incidence of EBV reactivation in patients with B-cell NHL was significantly lower than that in patients with T-cell NHL $(12.28 \% \pm 4.38 \%$ vs $28.96 \% \pm 4.82 \%, P=0.025)$.

In the subgroup analysis of B-cell NHL, the 100-day incidence of EBV reactivation was markedly decreased in the non-LBL group compared to the LBL group $(2.78 \% \pm 2.74 \%$ vs $28.57 \% \pm 9.86 \%, P=0.023$ ) (Table 2 ). In contrast, the incidence of EBV reactivation was lower in T-cell LBL than that in non-LBL T-cell lymphoma $(21.48 \% \pm 5.29 \%$ vs $36.93 \% \pm 8.87 \%, P=0.038)$. In patients receiving rituximab
pre-HCT $(n=43)$, only one patient experienced EBV reactivation on day +49 post-HCT.

The incidences of CMV reactivation were similar among different subgroups (Table 2). The 1-year incidences of CMV reactivation among patients who used ganciclovir $(n=83)$, foscarnet $(n=50)$, or acyclovir alone $(n=27)$ as prophylaxis were comparable $(27.26 \% \pm 5.10 \%$ vs $25.97 \% \pm 6.46 \%$ vs $25.17 \% \pm 9.12 \%, P=0.998)$.

\section{Risk factors for virus reactivation}

In the univariate analysis, more than 6 lines of chemotherapy $(P=0.023)$, advanced disease status pre-HCT $(\mathrm{P}=0.031)$, HLA-mismatched donors $(P=0.021)$, and the use of ATG $(P=0.006)$ were associated with EBV reactivation after HCT, while the use of rituximab $(P=0.010)$ was a protective factor (Online Resource1). Neutrophil recovery within 30 days post-HCT $(P=0.095)$ and autologous HCT before allo-HCT $(P=0.051)$ had marginal significance and were included in multivariate analysis. The multivariate analysis identified that more than 6 lines of chemotherapy $(\mathrm{HR}=2.272$, 95\% CI: 1.082-4.770, $P=0.030)$ independently increased the risk of EBV reactivation, while the use of rituximab $(\mathrm{HR}=0.054,95 \% \mathrm{CI}: 0.007-0.404, P=0.004)$ and neutrophil recovery within 30 days $(\mathrm{HR}=0.108,95 \%$ CI: $0.016-0.722, P=0.022)$ were independent protective factors (Fig. 1). Although no statistically significant risk factors were found for CMV reactivation in the whole cohort (Online Resource1, Fig. 1), the International Prognostic Index (IPI) $(P=0.015)$ and chronic GVHD $(P=0.001)$ were independent risk factors in T-cell LBL patients (Online Resource2).

\section{GVHD, relapse, and TRM}

Acute GVHD occurred in 89 recipients, of whom 64 (71.9\%) were grades II-IV and 40 (44.9\%) were grades III-IV. Chronic GVHD occurred in 45 patients, 21 of whom were extensive, with a median onset time of 183 (range, 110-1762) days after HCT. EBV reactivation was not associated with the occurrence of GVHD, but CMV reactivation was related to higher grade III-IV acute GVHD $(\mathrm{HR}=2.666$, 95\% CI: 1.153-6.614, $P=0.022$ ).

With a median follow-up for survivors of 21 months, the 2-year CIR of CMV-positive patients was decreased compared to that of CMV-negative patients $(13.7 \pm 0.3 \%$ versus $30.8 \pm 0.2 \%, P=0.049$ ) (Fig. 2b), and the 2-year TRM was comparable $(31.4 \pm 0.1 \%$ versus $19.9 \pm 0.0 \%, P=0.163)$ (Fig. 2d). Meanwhile, there were no significant differences in CIR $(P=0.778)$ and TRM $(P=0.759)$ between EBV-positive and EBV-negative patients (Fig. 2a, c). Only one patient developed and died from PTLD. 
In univariate analysis, CMV reactivation $(P=0.026)$ and neutrophil recovery within 30 days $(P=0.039)$ were associated with an improved CIR. However, only CMV reactivation ameliorated the CIR (HR $=0.265,95 \%$ CI: $0.081-0.860, P=0.027$ ) in multivariate analysis (Table 3 ). In addition, CMV reactivation $(P=0.040), \geq 8$ months from diagnosis to HCT $(P=0.042)$, and advanced disease status $(P=0.011)$ were significant risk factors for TRM in univariate analysis, while chronic
GVHD $(P=0.030)$, neutrophil recovery within 30 days $(P=0.022)$, and platelet recovery within 60 days $(P<0.001)$ were related to an improved TRM (Online Resource3). The results of multivariate analysis showed that only $\mathrm{CMV}$ reactivation $(\mathrm{HR}=2.257,95 \% \mathrm{CI}: 1.046-4.869, P=0.038)$ had a remarkable hazardous influence on TRM, while neutrophil recovery within 30 days was identified as an independent protective factor ( $\mathrm{HR}=0.189,95 \%$ CI: $0.049-0.723, P=0.015)$.
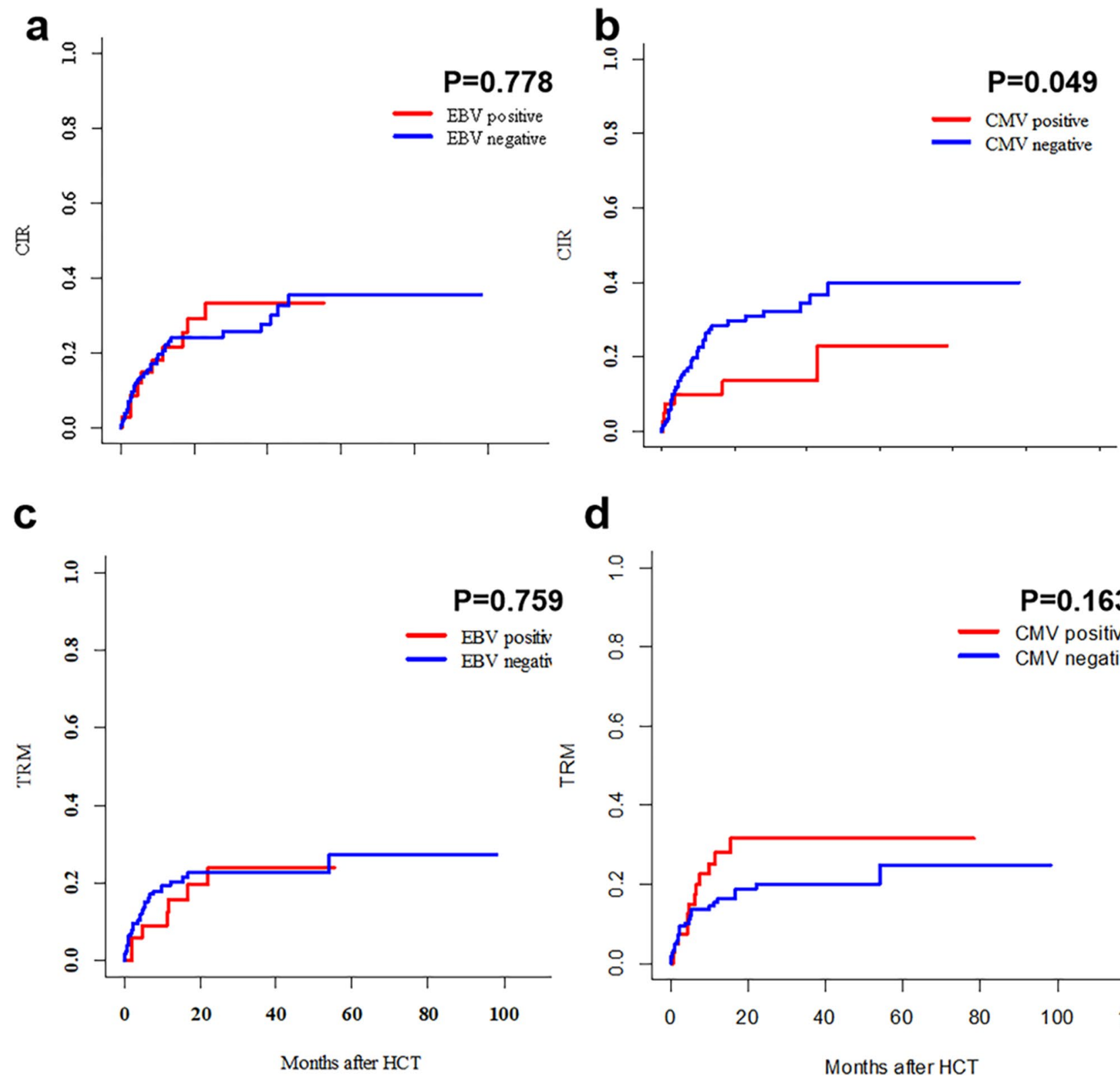

d

Fig. 2 Comparison of CIR and TRM for patients with or without virus reactivation after allo-HCT. a CIR of patients with or without EBV reactivation. b CIR of patients with or without CMV reactiva-

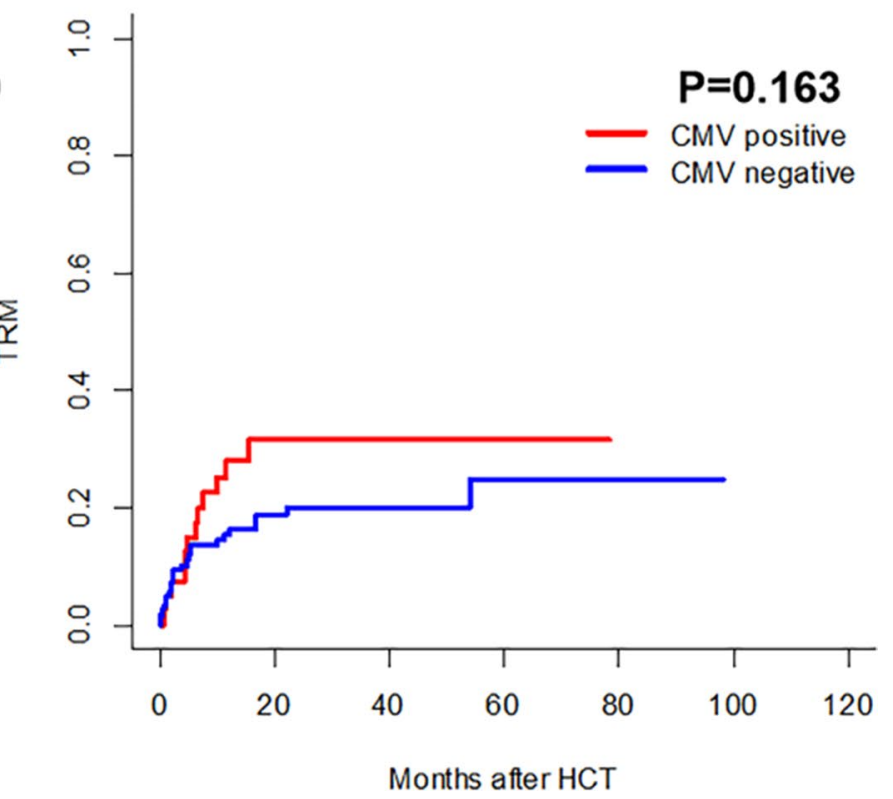

tion. c TRM of patients with or without EBV reactivation. d TRM of patients with or without CMV reactivation 


\section{OS, PFS, and GRFS}

Neither EBV nor CMV reactivation had a significant impact on OS (2-year OS: $58.1 \% \pm 9.7 \%$ for EBV-positive patients versus $69.2 \% \pm 4.3 \%$ for EBV negative patients, $P=0.573 ; 54.6 \% \pm 8.8 \%$ for CMV-positive patients versus $71.7 \% \pm 4.4 \%$ for CMV negative patients, $P=0.192$, respectively) or PFS (2-year PFS: $41.1 \% \pm 9.2 \%$ for EBVpositive patients versus $53.1 \% \pm 4.6 \%$ for EBV-positive patients, $P=0.949 ; 54.9 \% \pm 8.4 \% \mathrm{CMV}$-positive patients versus $48.6 \% \pm 4.9 \%$ for $\mathrm{CMV}$ negative patients, $P=0.551$, respectively) (Fig. 3). Chronic GVHD (HR $=0.303$, 95\% CI: $0.125-0.733, P=0.008$ ) and neutrophil recovery within
30 days $(\mathrm{HR}=0.190,95 \% \mathrm{CI}: 0.073-0.499, P=0.001)$ were associated with superior OS in multivariate analysis. Advanced disease status (HR $=0.192,95 \%$ CI: $0.082-0.447, P<0.001)$ and neutrophil recovery within 30 days (HR $=1.643,95 \%$ CI: $1.055-2.559, P=0.028$ ) were independent factors related to PFS in multivariate analysis (Table 3).

The CMV-positive group exhibited an inferior GRFS compared to the CMV-negative group (2-year GRFS: $12.9 \% \pm 5.9 \%$ versus $30.3 \% \pm 4.3 \%, P=0.024$ ) (Fig. 3 f), while no marked difference in GRFS was observed between the EBV-positive and EBV-negative groups (2-year GRFS: $21.3 \% \pm 7.5 \%$ versus $27.5 \% \pm 4.1 \%, P=0.619$ ) (Fig. $3 \mathrm{e}$ ).
Table 3 Multivariate Cox regression models about association between variables and outcomes

\begin{tabular}{|c|c|c|c|c|}
\hline & \multirow[t]{2}{*}{ HR } & \multicolumn{2}{|l|}{$95 \% \mathrm{CI}$} & \multirow[t]{2}{*}{$P$} \\
\hline & & Lower limit & Upper limit & \\
\hline \multicolumn{5}{|l|}{ OS } \\
\hline EBV: positive vs negative & 1.479 & 0.738 & 2.963 & 0.270 \\
\hline CMV: positive vs negative & 1.789 & 0.922 & 3.472 & 0.086 \\
\hline Disease status: advanced status vs CR & 1.800 & 0.997 & 3.249 & 0.051 \\
\hline TBI use: yes vs no & 1.419 & 0.800 & 2.518 & 0.232 \\
\hline Neutrophil recovery within 30 days: yes vs no & 0.190 & 0.073 & 0.499 & 0.001 \\
\hline \multicolumn{4}{|l|}{ PFS } & 0.008 \\
\hline Neutrophil recovery within 30 days: yes vs no & 0.192 & 0.082 & 0.447 & $<0.001$ \\
\hline Disease status: advanced status vs CR & 1.643 & 1.055 & 2.559 & 0.028 \\
\hline \multicolumn{5}{|l|}{ CIR } \\
\hline CMV: positive vs negative & 0.265 & 0.081 & 0.860 & 0.027 \\
\hline NCCN-IPI stratification & & & & 0.120 \\
\hline Low risk & 1 & & & \\
\hline Low-intermediate risk & 1.529 & 0.640 & 3.652 & 0.339 \\
\hline High-intermediate risk & 0.480 & 0.120 & 1.922 & 0.300 \\
\hline $\begin{array}{l}\text { Neutrophil recovery within } 30 \text { days: yes vs no } \\
\text { TRM }\end{array}$ & 0.359 & 0.109 & 1.181 & 0.092 \\
\hline CMV: positive vs negative & 2.257 & 1.046 & 4.869 & $\mathbf{0 . 0 3 8}$ \\
\hline Disease status: advanced status vs CR & 1.520 & 0.714 & 3.233 & 0.277 \\
\hline Time from diagnosis to HCT: $\geq 8 \mathrm{~m}$ vs $<8 \mathrm{~m}$ & 1.823 & 0.830 & 4.005 & 0.135 \\
\hline Rituximab: yes vs no & 1.847 & 0.912 & 3.740 & 0.088 \\
\hline Neutrophil recovery within 30 days: yes vs no & 0.189 & 0.049 & 0.723 & 0.015 \\
\hline Chronic GVHD: chronic GVHD vs none & 0.428 & 0.159 & 1.149 & 0.092 \\
\hline \multicolumn{5}{|l|}{ GRFS } \\
\hline EBV: positive vs negative & 1.575 & 0.932 & 2.661 & 0.089 \\
\hline CMV: positive vs negative & 1.741 & 1.035 & 2.927 & $\mathbf{0 . 0 3 7}$ \\
\hline IPI stratification & & & & 0.024 \\
\hline Low risk & 1 & & & \\
\hline Low-intermediate risk & 0.218 & 0.080 & 0.594 & 0.003 \\
\hline High-intermediate risk & 0.347 & 0.138 & 0.875 & 0.025 \\
\hline High risk & 0.300 & 0.114 & 0.791 & 0.015 \\
\hline Neutrophil recovery within 30 days: yes vs no & 0.325 & 0.148 & 0.712 & 0.005 \\
\hline
\end{tabular}

Abbreviations: $O S$ overall survival; $P F S$ progression-free survival; $C I R$ cumulative incidence of relapse; TRM treatment-related mortality; GRFS graft-versus-host disease-free with relapse-free survival 
CMV reactivation $(\mathrm{HR}=1.741,95 \%$ CI: $1.035-2.927$, $P=0.037)$, IPI $(P=0.024)$, and neutrophil recovery at 30 days (HR $=0.325,95 \%$ CI: $0.148-0.712, P=0.005)$ were independent predictors of GRFS in multivariate analysis (Table 3).

\section{Late effect of virus reactivation}

The late effect of virus reactivation was investigated in a subgroup of 120 patients who had viral reactivation within 100 days
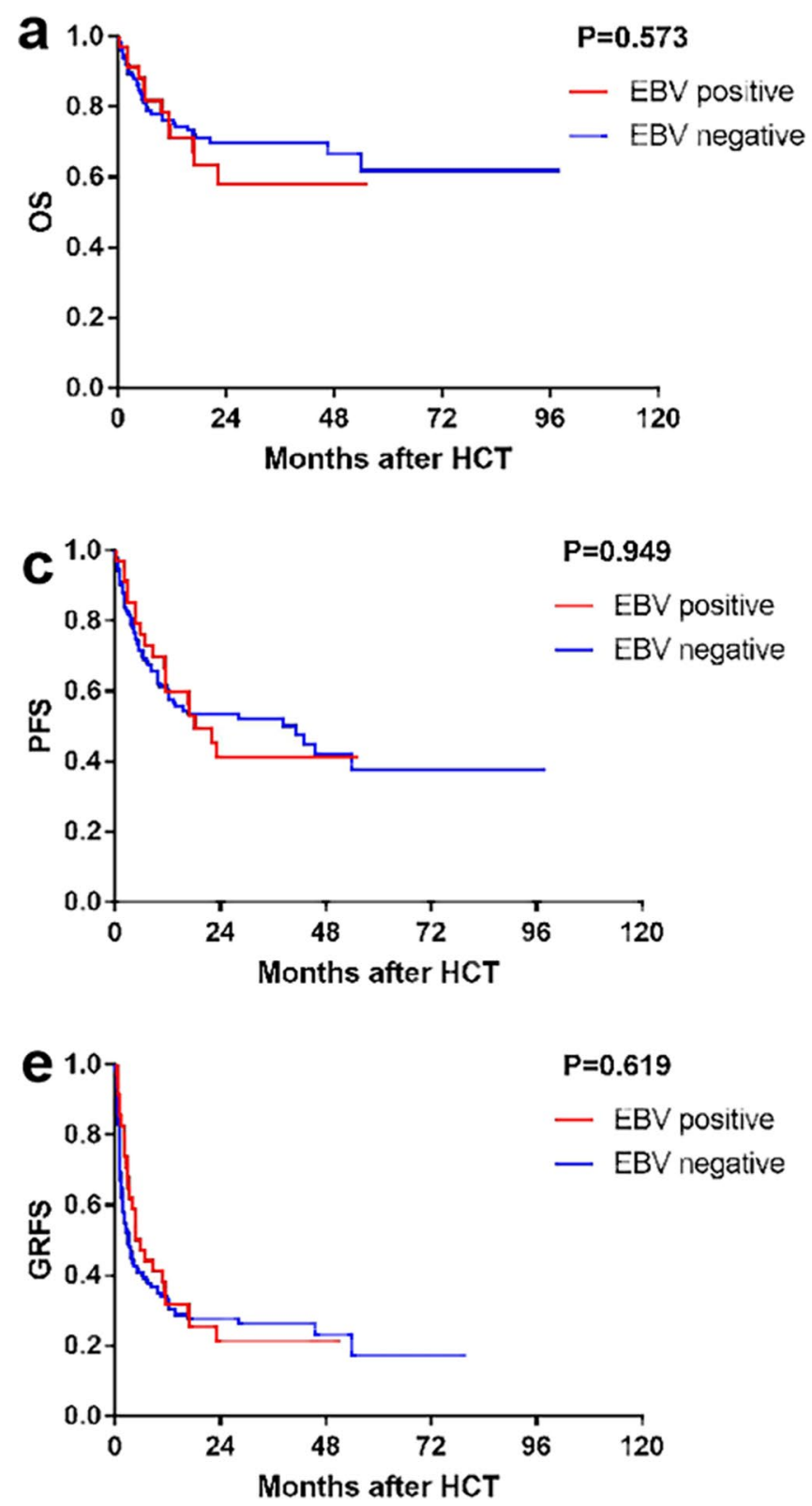

Fig. 3 Comparison of OS, PFS and GRFS for patients with or without virus reactivation after allo-HCT. a OS of patients with or without EBV reactivation. b OS of patients with or without CMV reactivation. $\mathbf{c}$ PFS of patients with or without EBV reactivation. d PFS and survived for more than 180 days post-HCT. Although the incidences of relapse (2-year CIR: $21.6 \% \pm 0.4 \%$ versus $29.5 \% \pm 0.3 \%, P=0.207$ ), PFS (2-year PFS: $56.1 \% \pm 8.1 \%$ versus $65.8 \% \pm 5.7 \%, P=0.682$ ), and GRFS (2-year GRFS: $19.2 \% \pm 6.3 \%$ versus $40.6 \% \pm 5.8 \%, P=0.053)$ were comparable, the virus reactivated group (either EBV or CMV) exhibited a significantly higher late TRM (2-year TRM: $20.1 \% \pm 0.5 \%$ versus $4.7 \% \pm 0.1 \%, P=0.020$ ), resulting in a lower OS (2-year OS: $67.6 \% \pm 8.0 \%$ versus $92.5 \% \pm 3.2 \%, P=0.005$ ) (Fig. 4 ).
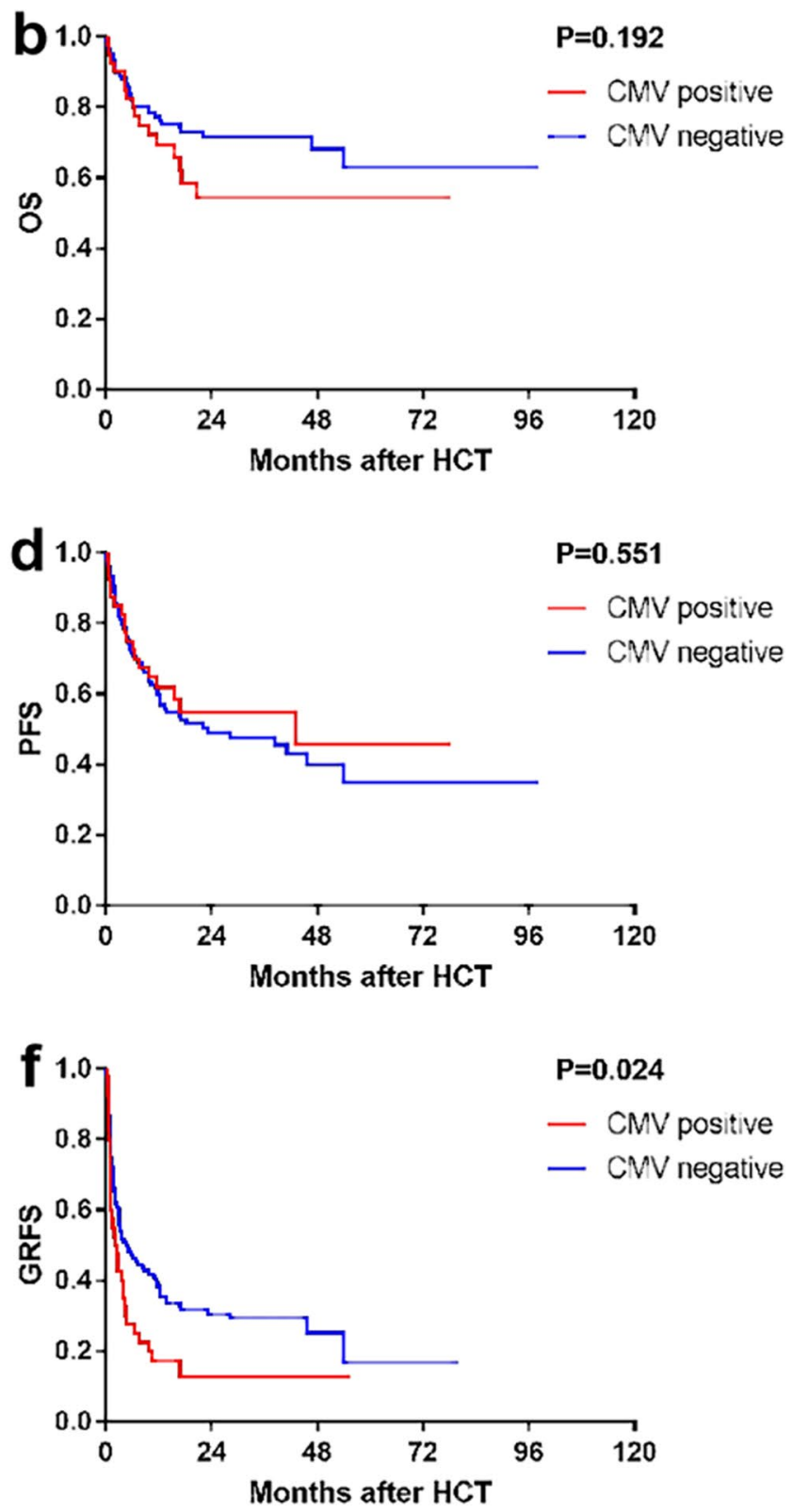

of patients with or without CMV reactivation. e GRFS of patients with or without EBV reactivation. f GRFS of patients with or without CMV reactivation 


\section{Discussion}

Both EBV and CMV reactivations are similarly common complications as a result of HCT-induced compromised
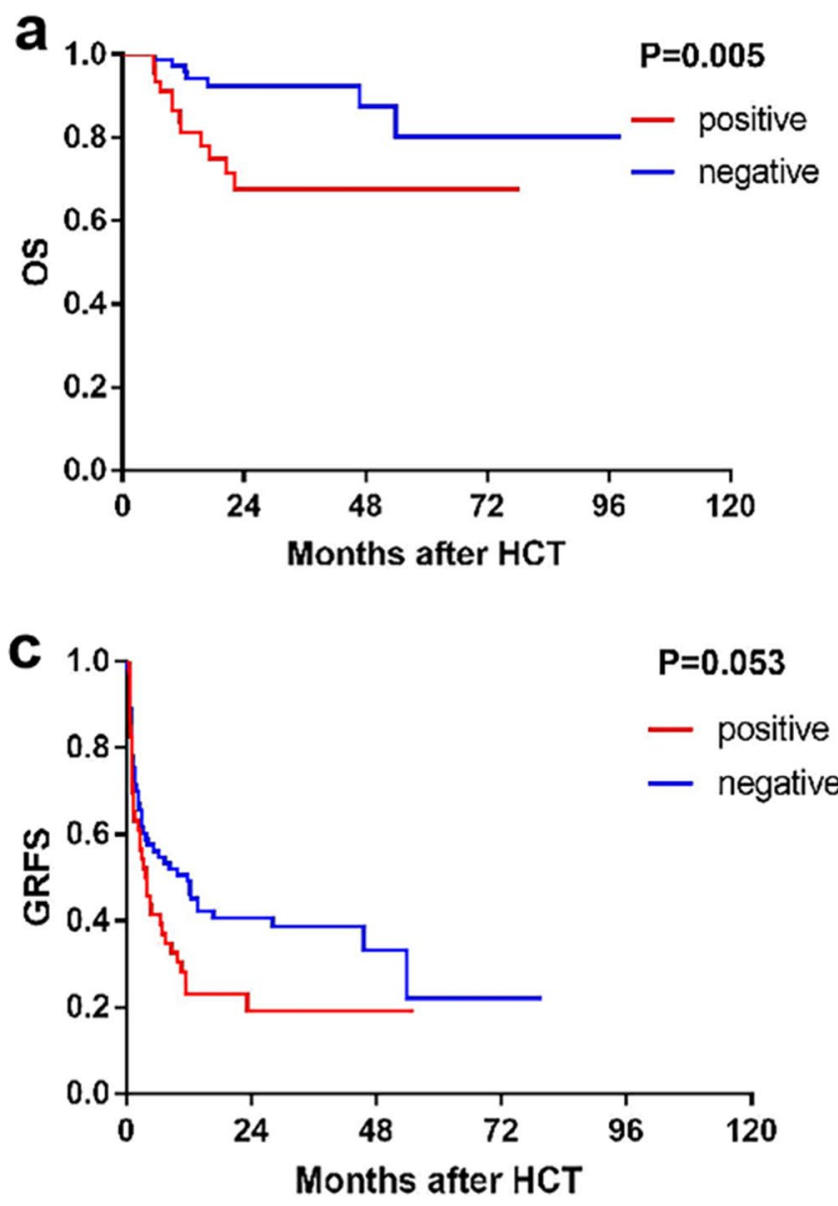

e

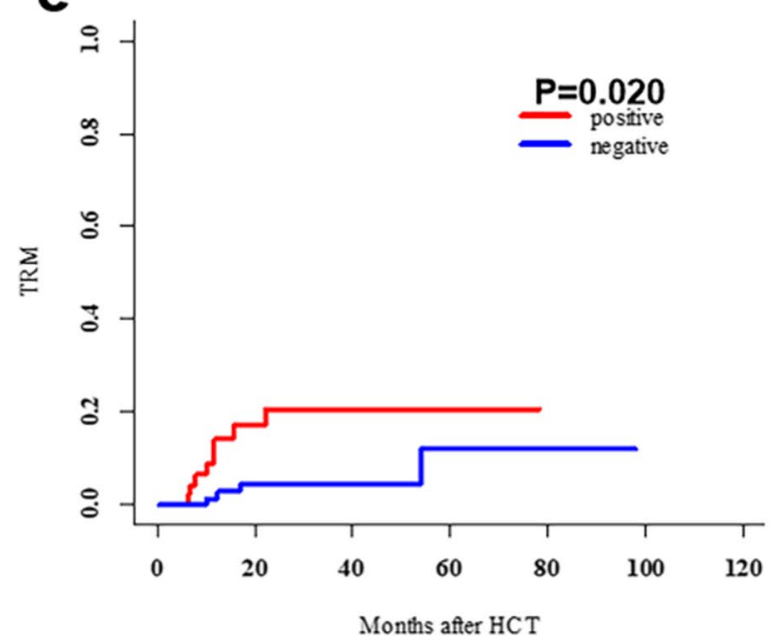

Fig. 4 Late effect on transplant outcomes of either EBV or CMV reactivation in patients survived for more than 180 days after alloHCT. a OS of patients with or without virus reactivation. b PFS of virus-specific immunity, which merits regular monitoring to avoid fatal EBV and CMV diseases. Although the growing proportion of haplo-HCT and ATG use increases the risk of virus reactivation after transplantation [25], the impact
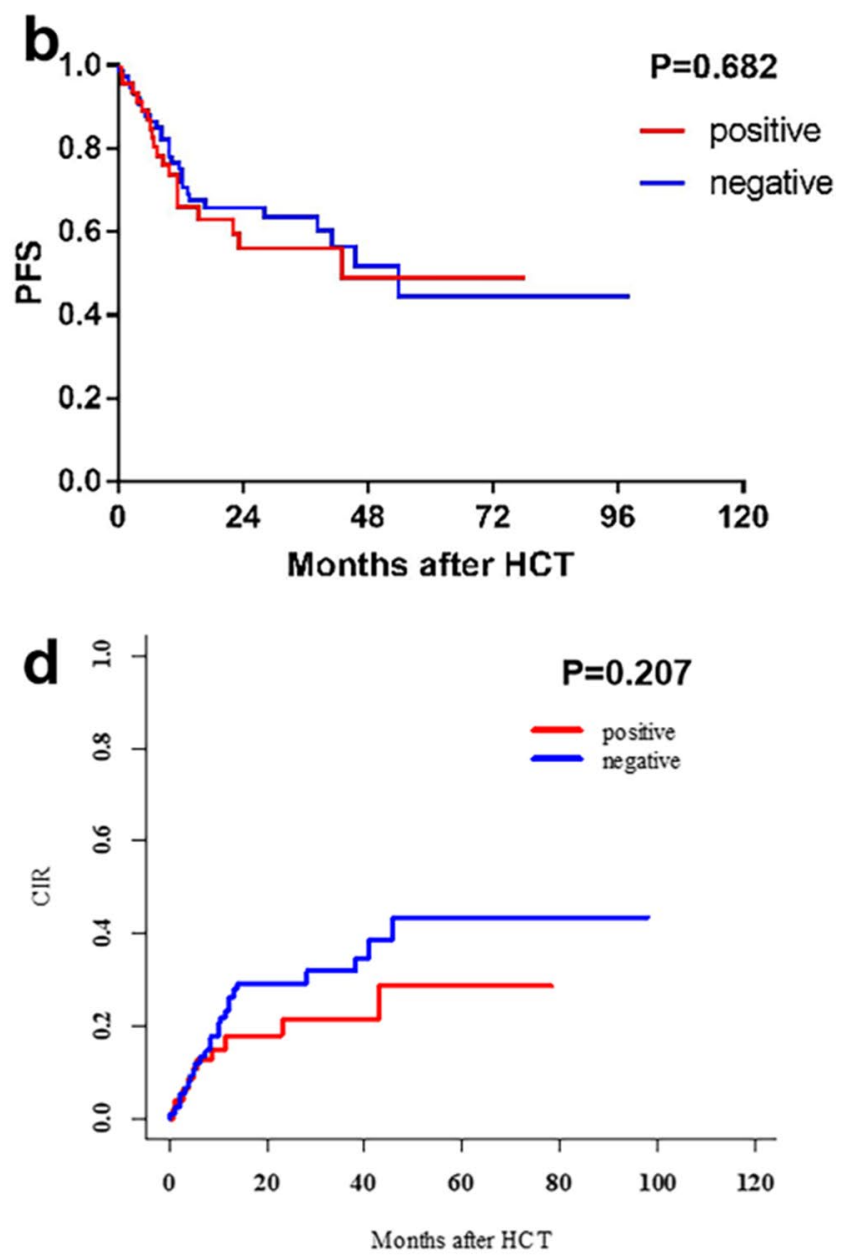

patients with or without virus reactivation. c GRFS of patients with or without virus reactivation. d CIR of patients with or without virus reactivation. e TRM of patients with or without virus reactivation 
might be compensated by the advances of anti-virus agents $[26,27]$. Since reports focusing on NHL patients were limited, we conducted this retrospective study to provide more data to benefit further studies in this field.

The incidence of EBV reactivation was significantly decreased in the non-LBL B-cell NHL group, which was probably attributed to the frequent application of rituximab in these patients[4, 28]. In the rituximab-treated subgroup, the only patient who developed EBV reactivation had a long interval from the last dose of rituximab to HCT (more than 1 year). In addition, we attributed the decreased incidence of EBV reactivation in T-cell LBL to fewer lines of chemotherapy $(P=0.001)$ and shorter interval from diagnosis to transplant $(P=0.011)$, since allotransplant was early recommended in most of these patients.

For EBV reactivation, HLA-mismatched donors and ATG use have been previously recognized as risk factors [25]. Recipients of HLA-mismatched donor HCT generally accept relatively stronger immunosuppressive therapy due to the HLA barrier, including ATG, which accordingly increases the risk of viral infection. In addition, we identified that previous chemotherapy of more than 6 lines and advanced disease status were independent factors for EBV reactivation. Complicated treatment courses and advanced disease status pre-HCT might indicate the aggressive nature of lymphoma, impaired hematopoietic capacity, and poorer performance. Neutrophil recovery within 30 days was an independent protective factor against EBV reactivation, which partially reflected the reservation of marrow function and fast immune reconstitution post-HCT [29, 30].

We did not find any independent risk factor for CMV reactivation in the whole cohort, which probably resulted from the homogenous transplant protocol in our center. Nevertheless, in T-cell LBL patients, the IPI and chronic GVHD were independently associated with CMV reactivation. A higher IPI score indicated a high tumor burden and worsened immune function that potentially facilitated CMV reactivation post-HCT. Meanwhile, an increased risk of chronic GVHD accompanied by CMV reactivation might result from the excessive activation of donor immune cells by CMV reactivation. Another evidence of such excessive activation was a decreased risk of CIR but an increased risk of grade 3-4 acute GVHD in CMV-positive patients in our cohort.

In accordance with our results, previous studies also demonstrated the protective effect of CMV reactivation against relapse or progression after allo-HCT in AML patients [17, 31, 32] as well as in NHL patients [33]. This protective effect might be mediated by CMV-driven expansion of donor-derived memory-like NKG2C + and NKG2D + natural killer cells, NKp46 cells, CD8 + T cells, and $\gamma / \delta \mathrm{T}$ cells to intensify the graft-versus-lymphoma (GVL) effect [34-37]. However, Green et al. [32] and
Mariotti et al. [38] failed to prove the protective effect of CMV reactivation after allo-HCT in a subgroup of NHL patients, so as Sawayama et al. [39] reported in 468 patients with T-cell leukemia/lymphoma. However, in all three of the abovementioned studies, CMV reactivation was monitored by pp65 antigenemia which was less sensitive than the Q-PCR method [40, 41], and a majority of recipients underwent reduced-intensity conditioning (RIC), which had a higher risk of relapse than MAC [42]. It was speculated that in patients who received RIC, host-derived memory $\mathrm{T}$ cells can persist for up to 6 months and contribute to immunity against $\mathrm{CMV}$, preventing early expansion of donor $\mathrm{T}$ cells and NK cells $[42,43]$. Moreover, the risk of grade III-IV acute GVHD was increased accompanied by CMV reactivation $(P=0.022)$. In our study, acute GVHD might be triggered by alloreactivity caused by the expansion of donor T cells against CMV reactivation, which led to worse TRM and GRFS.

Since the late effect of virus reactivation on transplant outcomes has been reported previously [25, 31], it was also explored in our cohort and found a poorer outcome for surviving recipients who had either EBV or CMV reactivation within 100 days post-HCT. Therefore, more effective measures should be further taken to control overt virus replication without compromising the virus-induced effect of anti-lymphoma, probably of EBV/ CMV-specific cytotoxic T cells [44-46] and novel antiviral drugs [47-49].

In conclusion, we described the features of EBV and CMV reactivation after allo-HCT in patients with NHL as well as their impact on transplant outcomes. These findings of this study were restricted by several limitations, including the inherited drawbacks of a single-center retrospective study, limited sample size, mostly high-risk diseases in the cohort, and relatively homogenous transplant protocol, etc. Large-scale multicenter prospective studies are needed to validate our findings, and further research is needed to improve the treatment outcomes concerning EBV and CMV reactivation post-HCT.

Supplementary Information The online version contains supplementary material available at https://doi.org/10.1007/s00277-021-04642-5.

Acknowledgements Samples were managed by Jiangsu Biobank of Clinical Resources.

Funding This work was supported by the National Natural Science Foundation of China (81730003, 81700173), National Science and Technology Major Project (2017ZX09304021), National Key R\&D Program of China (2019YFC0840604, 2017YFA0104502), Key R\&D Program of Jiangsu Province (BE2019798), Priority Academic Program Development of Jiangsu Higher Education Institutions (PAPD), Jiangsu Medical Outstanding Talents Project (JCRCA2016002) and Jiangsu Provincial Key Medical Center (YXZXA2016002), and Scientific Program of Health Commission of Jiangsu Province (H2018033). 
Data availability The datasets generated during and/or analyzed during the current study are available from the corresponding author on reasonable request.

\section{Declarations}

Ethics approval All procedures performed in studies involving human participants were in accordance with the ethical standards of the institutional research committee and with the 1964 Helsinki declaration and its later amendments or comparable ethical standards.

Informed consent Informed consent was obtained from all individual participants for enrolling relative data into an institutional database. The protocol of this study was approved by an institutional ethics committee.

Conflict of interest The authors declare no competing interests.

Open Access This article is licensed under a Creative Commons Attribution 4.0 International License, which permits use, sharing, adaptation, distribution and reproduction in any medium or format, as long as you give appropriate credit to the original author(s) and the source, provide a link to the Creative Commons licence, and indicate if changes were made. The images or other third party material in this article are included in the article's Creative Commons licence, unless indicated otherwise in a credit line to the material. If material is not included in the article's Creative Commons licence and your intended use is not permitted by statutory regulation or exceeds the permitted use, you will need to obtain permission directly from the copyright holder. To view a copy of this licence, visit http://creativecommons.org/licenses/by/4.0/.

\section{References}

1. Tsai T, Goodman S, Saez R, Schiller G, Adkins D, Callander N, Wolff S, Freytes CO (1997) Allogeneic bone marrow transplantation in patients who relapse after autologous transplantation. Bone Marrow Transplant 20:859-863. https://doi.org/10.1038/sj.bmt. 1700989

2. Paltiel O, Rubinstein C, Or R, Nagler A, Gordon L, Deutsch L, Polliack A, Naparstek E (2003) Factors associated with survival in patients with progressive disease following autologous transplant for lymphoma. Bone Marrow Transplant 31:565-569. https://doi. org/10.1038/sj.bmt.1703888

3. Epperla N, Hamadani M (2017) Hematopoietic cell transplantation for diffuse large B-cell and follicular lymphoma: current controversies and advances. Hematol Oncol Stem Cell Ther 10:277-284. https://doi.org/10.1016/j.hemonc.2017.05.004

4. Ru Y, Chen J, Wu D (2018) Epstein-Barr virus post-transplant lymphoproliferative disease (PTLD) after hematopoietic stem cell transplantation. Eur J Haematol 101:283-290. https://doi.org/10. 1111/ejh.13131

5. Gimenez E, Torres I, Albert E, Pinana JL, Hernandez-Boluda JC, Solano C, Navarro D (2019) Cytomegalovirus (CMV) infection and risk of mortality in allogeneic hematopoietic stem cell transplantation (Allo-HSCT): a systematic review, meta-analysis, and meta-regression analysis. Am J Transplant 19:2479-2494. https:// doi.org/10.1111/ajt.15515

6. Sundin M, Le Blanc K, Ringden O, Barkholt L, Omazic B, Lergin C, Levitsky V, Remberger M (2006) The role of HLA mismatch, splenectomy and recipient Epstein-Barr virus seronegativity as risk factors in post-transplant lymphoproliferative disorder following allogeneic hematopoietic stem cell transplantation. Haematologica 91:1059-1067

7. Engels EA (2007) Infectious agents as causes of non-Hodgkin lymphoma. Cancer Epidem Biomar 16:401-404. https://doi.org/ 10.1158/1055-9965.EPI-06-1056

8. Teras LR, Rollison DE, Pawlita M, Michel A, Brozy J, de Sanjose S, Blase JL, Gapstur SM (2015) Epstein-Barr virus and risk of non-Hodgkin lymphoma in the cancer prevention study-II and a meta-analysis of serologic studies. Int J Cancer 136:108-116. https://doi.org/10.1002/ijc.28971

9. Styczynski J, van der Velden W, Fox CP, Engelhard D, de la Camara R, Cordonnier C, Ljungman P (2016) Management of Epstein-Barr virus infections and post-transplant lymphoproliferative disorders in patients after allogeneic hematopoietic stem cell transplantation: Sixth European Conference on Infections in Leukemia (ECIL-6) guidelines. Haematologica 101: 803-811. https://doi.org/10.3324/haematol.2016.144428

10. Ljungman $\mathrm{P}$, de la Camara R, Robin C, Crocchiolo R, Einsele H, Hill JA, Hubacek P, Navarro D, Cordonnier C, Ward KN (2019) Guidelines for the management of cytomegalovirus infection in patients with haematological malignancies and after stem cell transplantation from the 2017 European Conference on Infections in Leukaemia (ECIL 7). The Lancet Infectious Diseases 19: e260-e272. https://doi.org/10.1016/S1473-3099(19)30107-0

11. Styczynski J, Czyzewski K, Wysocki M, Gryniewicz-Kwiatkowska O, Kolodziejczyk-Gietka A, Salamonowicz M, Hutnik L, Zajac-Spychala O, Zaucha-Prazmo A, Chelmecka-Wiktorczyk L, Siewiera K, Fraczkiewicz J, Malas Z, Tomaszewska R, IrgaJaworska N, Plonowski M, Ociepa T, Pierlejewski F, Gamrot Z, Urbanek-Dadela A, Gozdzik J, Stolpa W, Dembowska-Baginska B, Perek D, Matysiak M, Wachowiak J, Kowalczyk J, Balwierz W, Kalwak K, Chybicka A, Badowska W, Szczepanski T, Drozynska E, Krawczuk-Rybak M, Urasinski T, Mlynarski W, Woszczyk M, Karolczyk G, Sobol-Milejska G, Gil L (2016) Increased risk of infections and infection-related mortality in children undergoing haematopoietic stem cell transplantation compared to conventional anticancer therapy: a multicentre nationwide study. Clin Microbiol Infect 22:171-179. https://doi.org/10.1016/j.cmi.2015. 10.017

12. Bate SL, Dollard SC, Cannon MJ (2010) Cytomegalovirus seroprevalence in the United States: the national health and nutrition examination surveys, 1988-2004. Clin Infect Dis 50:1439-1447. https://doi.org/10.1086/652438

13. Jeon S, Lee WK, Lee Y, Lee DG, Lee JW (2012) Risk factors for cytomegalovirus retinitis in patients with cytomegalovirus viremia after hematopoietic stem cell transplantation. Ophthalmology 119:1892-1898. https://doi.org/10.1016/j.ophtha.2012.03.032

14. Teira P, Battiwalla M, Ramanathan M, Barrett AJ, Ahn KW, Chen M, Green JS, Saad A, Antin JH, Savani BN, Lazarus HM, Seftel M, Saber W, Marks D, Aljurf M, Norkin M, Wingard JR, Lindemans CA, Boeckh M, Riches ML, Auletta JJ (2016) Early cytomegalovirus reactivation remains associated with increased transplant-related mortality in the current era: a CIBMTR analysis. Blood 127:2427-2438. https://doi.org/10.1182/ blood-2015-11-679639

15. Styczynski J, Einsele H, Gil L, Ljungman P (2009) Outcome of treatment of Epstein-Barr virus-related post-transplant lymphoproliferative disorder in hematopoietic stem cell recipients: a comprehensive review of reported cases. Transpl Infect Dis 11:383-392. https://doi.org/10.1111/j.1399-3062.2009.00411.x

16. Auger S, Orsini M, Ceballos P, Fegueux N, Kanouni T, Caumes B, Klein B, Villalba M, Rossi JF (2014) Controlled Epstein-Barr virus reactivation after allogeneic transplantation is associated with improved survival. Eur J Haematol 92:421-428. https://doi. org/10.1111/ejh.12260 
17. Elmaagacli AH, Steckel NK, Koldehoff M, Hegerfeldt Y, Trenschel R, Ditschkowski M, Christoph S, Gromke T, Kordelas L, Ottinger HD, Ross RS, Horn PA, Schnittger S, Beelen DW (2011) Early human cytomegalovirus replication after transplantation is associated with a decreased relapse risk: evidence for a putative virus-versus-leukemia effect in acute myeloid leukemia patients. Blood 118:1402-1412. https://doi.org/10.1182/ blood-2010-08-304121

18. Hoegh-Petersen M, Sy S, Ugarte-Torres A, Williamson TS, Eliasziw M, Mansoor A, Liu Y, Liu S, Podgorny P, Khan F, Duggan PR, Stewart DA, Russell JA, Storek J (2012) High Epstein-Barr virus-specific T-cell counts are associated with near-zero likelihood of acute myeloid leukemia relapse after hematopoietic cell transplantation. Leukemia 26:359-362. https://doi.org/10.1038/ leu.2011.195

19. Wang Y, Wu DP, Liu QF, Xu LP, Liu KY, Zhang XH, Xu Y, Huang F, Huang XJ (2018) Donor and recipient age, gender and $\mathrm{ABO}$ incompatibility regardless of donor source: validated criteria for donor selection for haematopoietic transplants. Leukemia 32:492-498. https://doi.org/10.1038/leu.2017.199

20. Wang Y, Chen H, Chen J, Han M, Hu J, Jiong H, Huang H, Lai Y, Liu D, Liu Q, Liu T, Jiang M, Ren H, Song Y, Sun Z, Wang C, Wang J, Wu D, Xu K, Zhang X, Xu L, Liu K, Huang X (2018) The consensus on the monitoring, treatment, and prevention of leukemia relapse after allogeneic hematopoietic stem cell transplantation in China. Cancer Lett 438:63-75. https://doi.org/10. 1016/j.canlet.2018.08.030

21. Chen J, Wang RX, Chen F, Sun AN, Qiu HY, Jin ZM, Tang XW, Han Y, Fu ZZ, He GS, Miao M, Ma X, Wu DP (2014) Combination of a haploidentical SCT with an unrelated cord blood unit: a single-arm prospective study. Bone Marrow Transplant 49:206-211. https://doi.org/10.1038/bmt.2013.154

22. Chen J, Yang L, Fan Y, Xu Y, Han Y, Tang X, Qiu H, Fu C, Miao M, Chen F, Wu D (2018) Comparison of autologous stem cell transplantation versus haploidentical donor stem cell transplantation for favorable- and intermediate-risk acute myeloid leukemia patients in first complete remission. Biol Blood Marrow Transplant 24:779-788. https://doi.org/10.1016/j.bbmt.2017.12.796

23. Przepiorka D, Weisdorf D, Martin P, Klingemann HG, Beatty P, Hows J, Thomas ED (1995) 1994 Consensus Conference on Acute GVHD Grading. Bone Marrow Transplant 15: 825-828.

24. Filipovich AH, Weisdorf D, Pavletic S, Socie G, Wingard JR, Lee SJ, Martin P, Chien J, Przepiorka D, Couriel D, Cowen EW, Dinndorf P, Farrell A, Hartzman R, Henslee-Downey J, Jacobsohn D, McDonald G, Mittleman B, Rizzo JD, Robinson M, Schubert M, Schultz K, Shulman H, Turner M, Vogelsang G, Flowers ME (2005) National Institutes of Health consensus development project on criteria for clinical trials in chronic graft-versus-host disease: I. Diagnosis and staging working group report. Biol Blood Marrow Transplant 11:945-956. https://doi.org/10.1016/j.bbmt. 2005.09.004

25. Ru Y, Zhang X, Song T, Ding Y, Zhu Z, Fan Y, Xu Y, Sun A, Qiu H, Jin Z, Tang X, Han Y, Fu Z, Chen S, Ma X, Chen F, Chen J, Wu D (2020) Epstein-Barr virus reactivation after allogeneic hematopoietic stem cell transplantation: multifactorial impact on transplant outcomes. Bone Marrow Transpl 55:1754-1762. https://doi.org/10.1038/s41409-020-0831-7

26. Boeckh M, Ljungman P (2009) How we treat cytomegalovirus in hematopoietic cell transplant recipients. Blood 113:5711-5719. https://doi.org/10.1182/blood-2008-10-143560

27. Gooley TA, Chien JW, Pergam SA, Hingorani S, Sorror ML, Boeckh M, Martin PJ, Sandmaier BM, Marr KA, Appelbaum FR, Storb R, McDonald GB (2010) Reduced mortality after allogeneic hematopoietic-cell transplantation. N Engl J Med 363:2091-2101. https://doi.org/10.1056/NEJMoa1004383
28. Allen UD, Preiksaitis JK (2019) Post-transplant lymphoproliferative disorders, Epstein-Barr virus infection, and disease in solid organ transplantation: guidelines from the American Society of Transplantation Infectious Diseases Community of Practice. Clin Transplant 33:e13652. https://doi.org/10.1111/ctr.13652

29. Ozdemir ZN, Civriz BS (2018) Graft failure after allogeneic hematopoietic stem cell transplantation. Transfus Apher Sci 57:163-167. https://doi.org/10.1016/j.transci.2018.04.014

30. Tsai SB, Liu H, Shore T, Fan Y, Bishop M, Cushing MM, Gergis U, Godley L, Kline J, Larson RA, Martinez G, Mayer S, Odenike O, Stock W, Wickrema A, van Besien K, Artz AS (2016) Frequency and risk factors associated with cord graft failure after transplant with single-unit umbilical cord cells supplemented by haploidentical cells with reduced-intensity conditioning. Biol Blood Marrow Tr 22:1065-1072. https://doi.org/10.1016/j.bbmt. 2016.02.010

31. Takenaka K, Nishida T, Asano-Mori Y, Oshima K, Ohashi K, Mori T, Kanamori H, Miyamura K, Kato C, Kobayashi N, Uchida N, Nakamae H, Ichinohe T, Morishima Y, Suzuki R, Yamaguchi T, Fukuda T (2015) Cytomegalovirus reactivation after allogeneic hematopoietic stem cell transplantation is associated with a reduced risk of relapse in patients with acute myeloid leukemia who survived to day 100 after transplantation: the Japan Society for Hematopoietic Cell Transplantation Transplantation-related Complication Working Group. Biol Blood Marrow Transplant 21:2008-2016. https://doi.org/10.1016/j.bbmt.2015.07.019

32. Green ML, Leisenring WM, Xie H, Walter RB, Mielcarek M, Sandmaier BM, Riddell SR, Boeckh M (2013) CMV reactivation after allogeneic HCT and relapse risk: evidence for early protection in acute myeloid leukemia. Blood 122:1316-1324. https:// doi.org/10.1182/blood-2013-02-487074

33. Koldehoff M, Ross SR, Dührsen U, Beelen DW, Elmaagacli AH (2017) Early CMV-replication after allogeneic stem cell transplantation is associated with a reduced relapse risk in lymphoma. Leukemia Lymphoma 58:822-833. https://doi.org/10.1080/10428 194.2016.1217524

34. Koldehoff M, Lindemann M, Ross SR, Elmaagacli AH (2018) Cytomegalovirus induces HLA-class-II-restricted alloreactivity in an acute myeloid leukemia cell line. PLoS ONE 13:e191482. https://doi.org/10.1371/journal.pone.0191482

35. Jang JE, Hwang DY, Chung H, Kim SJ, Eom JI, Jeung HK, Song J, Kim JS, Cheong JW, Min YH (2019) Early Cytomegalovirus Reactivation and Expansion of CD56(bright)CD16(dim/-) DNAM1(+) Natural killer cells are associated with antileukemia effect after haploidentical stem cell transplantation in acute leukemia. Biol Blood Marrow Transplant 25:2070-2078. https://doi. org/10.1016/j.bbmt.2019.06.008

36. Foley B, Cooley S, Verneris MR, Pitt M, Curtsinger J, Luo X, Lopez-Verges S, Lanier LL, Weisdorf D, Miller JS (2012) Cytomegalovirus reactivation after allogeneic transplantation promotes a lasting increase in educated NKG2C+ natural killer cells with potent function. Blood 119:2665-2674. https://doi.org/10.1182/ blood-2011-10-386995

37. Scheper W, van Dorp S, Kersting S, Pietersma F, Lindemans C, Hol S, Heijhuurs S, Sebestyen Z, Grunder C, Marcu-Malina V, Marchant A, Donner C, Plachter B, Vermijlen D, van Baarle D, Kuball J (2013) gammadeltaT cells elicited by CMV reactivation after allo-SCT cross-recognize CMV and leukemia. Leukemia 27:1328-1338. https://doi.org/10.1038/leu.2012.374

38. Mariotti J, Maura F, Spina F, Roncari L, Dodero A, Farina L, Montefusco V, Carniti C, Sarina B, Patriarca F, Rambaldi A, Onida F, Olivieri A, Zallio F, Corradini P (2014) Impact of cytomegalovirus replication and cytomegalovirus serostatus on the outcome of patients with B cell lymphoma after allogeneic stem cell transplantation. Biol Blood Marrow Tr 20:885-890. https:// doi.org/10.1016/j.bbmt.2014.02.015 
39. Sawayama Y, Itonaga H, Fukushima T, Nakano N, Fujiwara H, Utsunomiya A, Fukuda T, Miyamoto T, Eto T, Miyashita K, Nakamae H, Ogata M, Yamanoha A, Miyazaki Y, Kanda J, Atsuta Y, Kato K (2019) Cytomegalovirus reactivation is associated with increased mortality more than 100 days after allogeneic hematopoietic stem cell transplantation for adult T-cell leukemia/lymphoma. Am J Hematol 94:E143-E146. https://doi.org/10.1002/ ajh. 25438

40. Allice T, Enrietto M, Pittaluga F, Varetto S, Franchello A, Marchiaro G, Ghisetti V (2006) Quantitation of cytomegalovirus DNA by real-time polymerase chain reaction in peripheral blood specimens of patients with solid organ transplants: comparison with end-point PCR and pp65 antigen test. J Med Virol 78:915-922. https://doi.org/10.1002/jmv.20641

41. Marchetti S, Santangelo R, Manzara S, D’Onghia S, Fadda G, Cattani P (2011) Comparison of real-time PCR and pp65 antigen assays for monitoring the development of Cytomegalovirus disease in recipients of solid organ and bone marrow transplants. New Microbiol 34:157-164

42. Manjappa S, Bhamidipati PK, Stokerl-Goldstein KE, DiPersio JF, Uy GL, Westervelt P, Liu J, Schroeder MA, Vij R, Abboud CN, Fehniger TA, Cashen AF, Pusic I, Jacoby M, Meera SJ, Romee R (2014) Protective effect of cytomegalovirus reactivation on relapse after allogeneic hematopoietic cell transplantation in acute myeloid leukemia patients is influenced by conditioning regimen. Biol Blood Marrow Tr 20:46-52. https://doi.org/10.1016/j.bbmt. 2013.10.003

43. Maris M, Boeckh M, Storer B, Dawson M, White K, Keng M, Sandmaier B, Maloney D, Storb R, Storek J (2003) Immunologic recovery after hematopoietic cell transplantation with nonmyeloablative conditioning. Exp Hematol 31:941-952. https://doi.org/10. 1016/S0301-472X(03)00201-7

44. Neuenhahn M, Albrecht J, Odendahl M, Schlott F, Dossinger G, Schiemann M, Lakshmipathi S, Martin K, Bunjes D, Harsdorf S, Weissinger EM, Menzel H, Verbeek M, Uharek L, Kroger N, Wagner E, Kobbe G, Schroeder T, Schmitt M, Held G, Herr W, Germeroth L, Bonig H, Tonn T, Einsele H, Busch DH, Grigoleit GU (2017) Transfer of minimally manipulated CMV-specific T cells from stem cell or third-party donors to treat CMV infection after allo-HSCT. Leukemia 31:2161-2171. https://doi.org/10. 1038/leu.2017.16

45. Shafat MS, Mehra V, Peggs KS, Roddie C (2020) Cellular therapeutic approaches to cytomegalovirus infection following allogeneic stem cell transplantation. Front Immunol 11:1694. https:// doi.org/10.3389/fimmu.2020.01694

46. Heslop HE, Slobod KS, Pule MA, Hale GA, Rousseau A, Smith CA, Bollard CM, Liu H, Wu MF, Rochester RJ, Amrolia PJ, Hurwitz JL, Brenner MK, Rooney CM (2010) Long-term outcome of EBV-specific T-cell infusions to prevent or treat EBVrelated lymphoproliferative disease in transplant recipients. Blood 115:925-935. https://doi.org/10.1182/blood-2009-08-239186

47. Marty FM, Ljungman P, Chemaly RF, Maertens J, Dadwal SS, Duarte RF, Haider S, Ullmann AJ, Katayama Y, Brown J, Mullane KM, Boeckh M, Blumberg EA, Einsele H, Snydman DR, Kanda Y, DiNubile MJ, Teal VL, Wan H, Murata Y, Kartsonis NA, Leavitt RY, Badshah C (2017) Letermovir prophylaxis for cytomegalovirus in hematopoietic-cell transplantation. N Engl J Med 377:2433-2444. https://doi.org/10.1056/NEJMoa1706640

48. Maertens J, Cordonnier C, Jaksch P, Poire X, Uknis M, Wu J, Wijatyk A, Saliba F, Witzke O, Villano S (2019) Maribavir for preemptive treatment of cytomegalovirus reactivation. N Engl J Med 381:1136-1147. https://doi.org/10.1056/NEJMoa1714656

49. Marty FM, Winston DJ, Chemaly RF, Mullane KM, Shore TB, Papanicolaou GA, Chittick G, Brundage TM, Wilson C, Morrison ME, Foster SA, Nichols WG, Boeckh MJ (2019) A randomized, double-blind, placebo-controlled phase 3 trial of oral brincidofovir for cytomegalovirus prophylaxis in allogeneic hematopoietic cell transplantation. Biol Blood Marrow Transplant 25:369-381. https://doi.org/10.1016/j.bbmt.2018.09.038

Publisher's note Springer Nature remains neutral with regard to jurisdictional claims in published maps and institutional affiliations. 